\title{
Identity Options and Cultural Representations in English Textbooks Used in Cambodia
}

\author{
Jia $\mathrm{Li}^{1}$, Juan Dong ${ }^{1} \&$ Wei Duan ${ }^{1}$ \\ ${ }^{1}$ School of Foreign Languages, Yunnan University, Kunming, China \\ Correspondence: Juan Dong, School of Foreign Languages, Yunnan University, Kunming, China. E-mail: \\ 18722808274@139.com
}

Received: October 4, 2019

Accepted: October 11, 2019

Online Published: October 21, 2019

doi:10.5539/ass.v15n11p60

URL: https://doi.org/10.5539/ass.v15n11p60

This work was supported by Yunnan University under the Grant [No.18YNUGSP015] and [No.18YNUGSP051] and funded by the College of Foreign Languages of Yunnan University under the Grant [C176210301].

\begin{abstract}
Language textbooks play an important role in bridging learners' understanding between the source culture and target culture. This study explores how the Cambodian and foreign characters are produced and how the source and target cultures are represented in three English language textbooks published by the Cambodian Ministry of Education, Youth and Sport (MoEYS). The data were collected from textbook passages, exercises and images presented in the textbooks and the data were analyzed based on the emerging themes in language and cultural representations of the textbooks. The findings indicate that regarding the distribution in the target communities, Anglophone and their postcolonial countries are prominently highlighted in the textbooks with the exception that Japan is exclusively introduced as imagined interlocutor for cultural communication; concerning the representation of the source culture, Buddhism and Khmer are constructed as legitimate forms of Cambodian practices. Based on the findings, we argue that English textbooks produced in Cambodia have not provided Cambodian youth with balanced exposure of cultural diversity. The study has implications for designing English textbooks with the consideration of diverse identity options and cultural representations.
\end{abstract}

Keywords: identity options, cultural representations, English textbooks, Cambodia

\section{Introduction}

In the globalized era, English has spread on a huge scale all over the world (Crystal, 2003; Graddol, 2006; Jenkins, 2015). With English becoming increasingly significant for achieving success in $21^{\text {st }}$ century global competition, English has been adopted as an official language used in the Association of South East Asian Nations (ASEAN) (Zein, 2017). The Kingdom of Cambodia, as one of the members of ASEAN, has been dominated by the impact of global, international and national status of English language. English plays a significant role in Cambodia both politically and economically. After gaining independence in 1953, English has become popular in connecting Cambodia to the rest of ASEAN and in enhancing its local economy via the tourism industry. The boom of the tourism and hospitality industry is probably the most compelling reason and the strongest incentive for learning English among the young generations in Cambodia (Kasanga, 2012)。

Apart from the lucrative tourism, English is also widely adopted in various businesses, foreign investments and educational settings, symbolizing modernity, prosperity and many other economic benefits (Kasanga, 2012). Seeing the importance of English language in Cambodia, there have emerged major educational reforms in Cambodia supported by international funding, and the vital role of English has increased due to its vitality in social development and modernization (Tweed \& Som, 2015). English was conceptualized as a foreign language in the Cambodian education system in the late 1980s by the Ministry of Education, Youth and Sport (MoEYS) (Moore \& Bounchan, 2010; Neau, 2003), and it has recently become the official language of the ASEAN (Tweed \& Som, 2015).

As a matter of fact, Education is the domain in which English tends to burgeon. Thus, English has been a curriculum subject for Cambodian middle school students, at least since 1989 (Neau, 2003). Additionally, the introduction of English instruction to primary school students reflects the government's recognition of the 
significance of English for national development. Among all of language teaching materials, language textbooks are considered as the primary tool for providing knowledge in the classroom (Peled-Elhanan, 2012). For language beginners, the cultural representations in textbooks will greatly affect students' recognition and world values.

English language textbooks are not only used to impact linguistic knowledge, but also considered as the main resource for learning different cultural aspects of English. Thus, language textbooks constitute a hidden curriculum that embodies particular ideologies and legitimizes specific types of knowledge (Canale, 2016). Following this line of inquiry, this paper explores the identity options and cultural representations of the English textbooks for Cambodian middle school students.

\section{Previous Studies on English Language Textbooks}

Many scholars have investigated the cultural representations of English textbooks in different contexts, such as Japan, Australia, Iran, England, Uganda, Saudi Arabia, Pakistan and so on (Yamada, 2010; Lee \& Collins, 2010; Hodkinson, 2018; Stranger-Johannessen, 2015; Alshammri, 2017; Mohamood, 2012). In these previous studies, thematic topics like cultural representation, identity construction, and gender stereotypes were reported and analyzed. For instance, Alshammri (2017) evaluated the representations of identity options and cultural elements in English language textbooks used in Saudi Arabia under the framework of Critical Discourse Analysis, showing that the oversimplifications and misrepresentations of foreign characters and foreign cultures may have a negative impact on learner's motivation or may lead to weak English competence. Similarly, Taira (2019) revealed that the Nihonjinron discourse operating produces a position subjected to the discourse of Japanization within which Okinawans become "Japanese". He problematized these discursive texts as a systematic form of Japanizing Okinawans' minds through education. Also, Lee \& Collins (2010) examined gender construction both in Australia and Hong Kong, revealing the convention that women were depicted as more passive and weaker than men. As one of the ancient civilizations in Southeast Asia, however, little is known about the English textbooks used in Cambodia. Language textbooks are not only an important source for conveying subject knowledge but also impact their underlying beliefs on their effectiveness in conveying knowledge to language learners (Alshammri, 2017, p. 9). Thus, studying Cambodia's English textbooks is one of the essential ways to understand the current situation of English language learning in Cambodia.

\section{Hegemony and Ideology as Theoretical Concepts}

The concepts of hegemony and ideology are two vital terms in language education and culture. Gramsci (1971) sees hegemony as powerful groups use to dominate subjects whereby the latter accept dominance as natural and apply it in the interests of the former without objection. Hegemony is applied via channels with a limited use of actual force but is nonetheless supported by unequal structures of power (Richardson 2007). In this case, both the dominant and the dominated groups take hegemony for granted as it is validated through natural and legitimate forms of social interaction, socio-cultural values and assumptions as well as through discursive practices. Moreover, Mohamed (2014, p. 55) asserts that hegemony refers to power and domination in the domains of economics, politics, cultural life and ideology within a certain society or across societies. Gramsci also notes that one of the most "... critical element[s] to promote and enhance the ideological hegemony in certain classes is often done through the control of knowledge" (Apple, 1990, p. 26). In this context, the rationing of knowledge tends to serve the needs of a single interested party rather than individuals or society (Apple, 1990). Thus, language and knowledge play a major role in terms of hegemonic control in the social world.

Furthermore, ideology is another term discussed in studies of language and education. Gee (1990, p. 3) affirms that ideology refers to “... the ideas, beliefs, principles and values that a person has". Mohamed (2014, pp. 53-54) maintains that ideology is the set of beliefs which is used by the powerful to sustain inequality across a society or between societies. In this sense, ideology is employed through discursive and visual practices to serve and sustain asymmetrical power relations either nationally or internationally. In this respect, the powerful employ various tactics so as to obscure and deceive the less powerful such that the illegitimate becomes legitimate and the inappropriate becomes appropriate (Wooffitt, 2005). Fairclough asserts that "...language is a material form of ideology, and language is invested by ideology" (1995, p. 73). Li, Ai \& Zhang's study (2019) indicates that Myanmar high school students' language investment is shaped by their language ideologies which in turn impact their cultural identifications. Meanwhile, Li, Dong \& Li's study (2019) also illustrated that multiple ideologies of shaping Cambodian Students' language learning experiences at Chinese universities. Language is manipulated in order to serve the interests of the powerful and privileged at the expense of the disempowered and less privileged. Ideology in textbooks represents itself in texts and images. Therefore, ideology is presented within the form and content of texts. This implies that textbooks are social products that offer service to students by providing them 
with linguistic, cultural and educational ideological inputs (Mohamed, 2014, p. 55). In short, hegemony and ideology are two important factors that cannot be ignored when studying English language textbooks. We ask two research questions concerning the ideological representations of identity and culture produced in the Cambodian English language textbooks.

(1) How are the Cambodian and foreign characters displayed in the textbooks?

(2) How is the Cambodian (source) and foreign (target) culture represented in the textbooks?

\section{Methodology}

\subsection{Material Selection}

In Cambodia, several different series of language textbooks are mainly designed by the Ministry of Education, Youth and Sport. Cambodia has been an underdeveloped country with poverty because of its historical factors. However, Japan is a powerful country in Southeast Asia. Japan's current policy-making approach towards Southeast Asia may be regarded as a continuation of policy that is, nevertheless, being buffeted by a range of primarily regional - external influences. Besides, Julie (2004) examines that Japanese government manages changing circumstances to carve out a new role for itself in Southeast Asia. At the same time, Cambodia, as one of the members of Southeast Asia, obviously will be the target of Japan's policy, particularly in education.

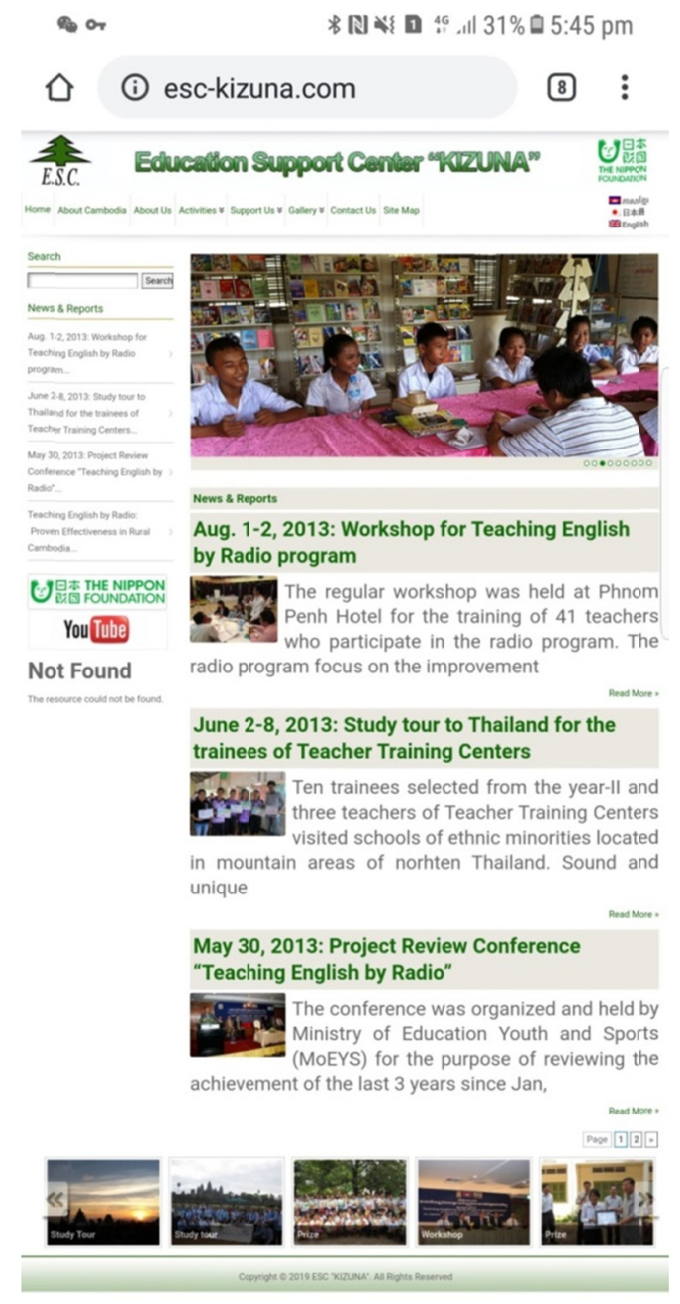

Figure 1. Screenshot from website: http://www.esc-kizuna.com/

As is shown in Figure 1, from the upper right corner of the picture, we can see the Japanese logo 'The Nippon Foundation' which is placed on the top, followed by the language choices of Khmer, Japanese and English as well as the national flags of the three countries. It indicates that Japan and The United Kingdom support the English education of Cambodia. Interestingly, Japan is the main supporter of Cambodian education. In this case, the research is going to choose the three English Textbooks, grade 7, 8 and 9 for middle schools, which have 
been produced by Japanese organization--The Nippon Foundation. From the cover of this series books, we will clearly see two Japanese symbols in Figure 2-'THE NIPPON FOUNDATION' and 'Education Support Center KIZUNA NGO', which were located at the right bottom of the cover.

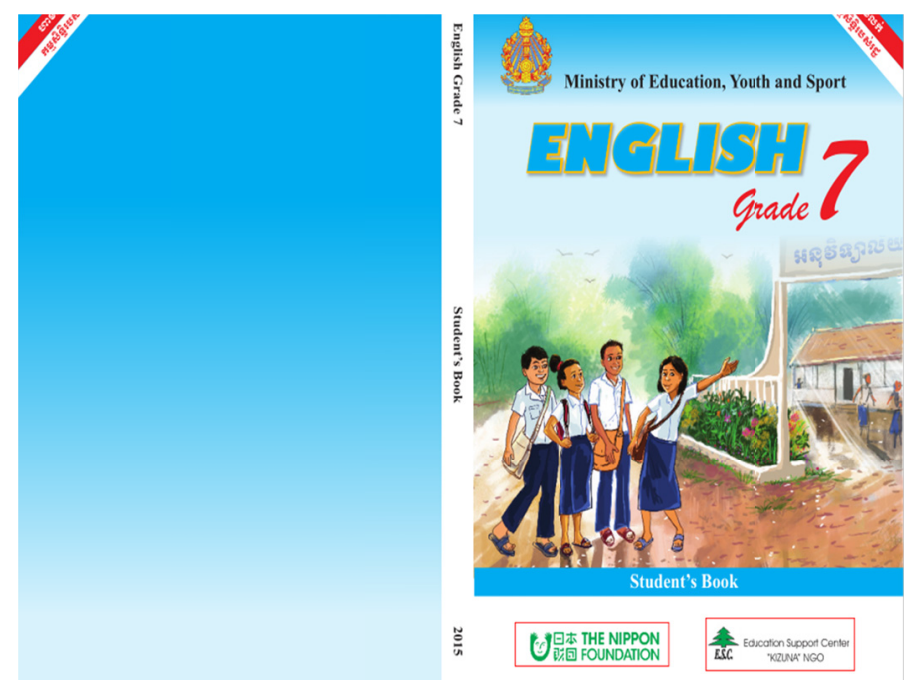

Figure 2. The cover of Student's Book, Grade 7

\subsection{Data Analysis}

In order to consider both foreign and Cambodian characters and cultural representations, content analysis (CA) was employed for present study. Content analysis is a research method that uses a set of procedures to make valid inferences from text. Compared with other data-generating and analysis techniques, content analysis has several advantages: (i) Communication is a central aspect of social interaction. Content-analytic procedures operate directly on text or transcripts of human communications. (ii) In more recent times, when reliable data of other kinds exist, culture indicators can be used to assess quantitatively the relationships among economic, social, political, and cultural change and so forth (Robert, 1990). Researchers regard content analysis as a flexible method for analyzing text data (Cavanagh, 1997). In addition, Content analysis classifies textual material, reducing it to more relevant, manageable bits of data.

Thus, we were careful to comprehensively collect and analyze all the data within the three Cambodian English textbooks that related to the research questions. As Aiello (2006) states that the role of images is (in part) to carry cultural meanings. Images play a powerful role in the construction of truth and reality (Hyatt, 2005, p. 52). Therefore, images and texts jointly introduce a certain reality. However, Paltridge (2006, p. 106) points out that "[m] any readings of texts are constructed not just by the use of words but by a combination of words with other modalities of communication, such as pictures, films, video images and sounds." Regarding this, content analysis and critical image analysis framework were combined to collect some texts and figures from the three textbooks.

\section{Findings}

In this part, the findings in relation to the first research question, "How are the Cambodian and foreign characters displayed in the textbooks?" To answer this question, we analyzed the set of characters, their gender, occupation and nationality for Cambodian and foreign characters offered in the three textbooks. The findings are presented in Table 1, 2, 3 and 4.

\subsection{Identity Options between the Source and Target Countries}

\subsubsection{Characters}

Table1. Character distribution in the three MoEYS series textbooks

\begin{tabular}{ccc}
\hline Types of characters & Cambodian characters (Source) & Foreign characters (target) \\
\hline Number & 74 & 39 \\
Percentage $(\mathrm{N}=113)$ & $65.49 \%$ & $34.51 \%$ \\
\hline
\end{tabular}

Table 1 shows that the number of the characters represented in the MoEYS series is 113, including 74 Cambodian characters and 39 non-Cambodian characters. By comparing the number of Cambodia and foreign 
characters in the three textbooks, it is clear that the representation of Cambodian characters $(65.49 \%)$ is higher than that of foreign characters $(34.51 \%)$.

\subsubsection{Gender}

Table 2. Gender distribution in the three MoEYS series textbooks

\begin{tabular}{ccccccc}
\hline Gender and nationality & Cambodian male & Cambodian female & Unknown & Foreign male & Foreign female & Unknown \\
\hline Number & 34 & 31 & 9 & 16 & 19 & 4 \\
Percentage $(\mathrm{N}=113)$ & $30.09 \%$ & $27.43 \%$ & $7.96 \%$ & $14.16 \%$ & $16.81 \%$ & $3.54 \%$ \\
\hline
\end{tabular}

In terms of the gender distribution, Table 2 shows that Cambodian male and female are shared almost the equal numbers (34 male and 31 female). At the same time, in the case of foreign characters, there is a slight number gap between male and female characters (16 male and 19 female), indicating that in this series book, there is not an obvious imbalanced gender distribution and under-representation of Cambodian and non-Cambodian female characters.

\subsubsection{Occupation}

Table 3. Occupational identities of characters in the three MoEYS series textbooks

\begin{tabular}{|c|c|c|c|c|c|}
\hline \multicolumn{3}{|c|}{ Cambodian Characters } & \multicolumn{3}{|c|}{ Foreign Characters } \\
\hline Occupational identity & Male 38 & Female 36 & Occupational identity & Male 19 & Female 18 \\
\hline Teacher & - & 1 & Teacher & - & - \\
\hline School principal & 1 & - & Student & 16 & 16 \\
\hline Student & 29 & 26 & Footballer & 1 & - \\
\hline Cook & 1 & 1 & Musician & 1 & - \\
\hline Gardener & - & 1 & Singer & - & 1 \\
\hline Singer & 2 & 4 & Baseball player & 1 & - \\
\hline Musician & 1 & - & Health worker & - & 1 \\
\hline Dancer & - & 1 & & & \\
\hline Housewife & - & 1 & & & \\
\hline zookeeper & 1 & - & & & \\
\hline Doctor & 1 & - & & & \\
\hline Officer & 1 & - & & & \\
\hline Photographer & - & 1 & & & \\
\hline Farmer & 1 & - & & & \\
\hline
\end{tabular}

Table 3 shows the occupations of the Cambodia and foreign characters represented in the MoEYS series. Cambodian characters have been assigned 14 occupations, while 7 (less than 10) occupations have been assigned to foreigners. It is obviously demonstrates that the MoEYS series Cambodian English textbooks play more attention to domestic occupations but not foreign countries. According to the number of the male and female occupations in Cambodia (38 male and 36 female) and Foreign countries (19 male and 18 female), there is almost an equal distribution. However, comparing the occupations of Cambodia and foreign countries offered in the three textbooks, the occupations offered in Cambodia almost represent the low and middle-class (cook, gardener, housewife, zookeeper and so on), while occupations attached foreigners (footballer, musician, singer, baseball player, health worker and so on) are constructed as middle- or upper-class.

\subsubsection{Nationality}

Table 4. Nationality distribution in the three MoEYS series textbooks

\begin{tabular}{|c|c|c|c|c|}
\hline & Nationality & Male 43 & Female 44 & Undefined \\
\hline & UK & - & 2 & \\
\hline & England & 2 & - & \\
\hline & Ireland & - & 1 & \\
\hline \multirow[t]{4}{*}{ Europe } & Italy & - & & \\
\hline & Spain & - & & \\
\hline & Russia & - & - & \\
\hline & France & & - & \\
\hline
\end{tabular}




\begin{tabular}{ccccc}
\hline \multirow{3}{*}{ Americas } & Canada & 1 & 3 & \\
& America(US) & - & 2 & - \\
& Brazil & - & - & 1 \\
China & 1 & - & - \\
& Mongolia & 1 & - & 1 \\
Japan & - & 4 & - \\
Asia & India & - & - & - \\
& Thailand & - & - & 1 \\
& Laos & & & - \\
& Malaysia & 1 & & - \\
& Vietnam & 1 & - & 1 \\
& Cambodia & 34 & - & - \\
Africa & Indonesia & - & - & - \\
& Philippines & - & - & 1 \\
\hline \multirow{2}{*}{ Oceania } & Kenya & - & - & \\
& South Africa & 1 & 1 & - \\
\hline
\end{tabular}

In these English textbooks, the representation of the world is Anglophone-centered in that English speaking countries like UK, USA, Canada, Ireland, Australia and their previously-colonized countries such as South Africa, India, Malaysia are represented as the targeting countries. The world for young Cambodian students to be exposed to is de facto dominated by the English-speaking countries. Apart from the representation of the English-speaking world order, Asian countries also find their places in the textbooks where Japan constitutes the prominent space given its main funding source for compiling the textbooks. For the rest of the Asian countries produced, Southeast Asian countries such as Malay, Indonesia, Vietnam are depicted as important cooperating partners for Cambodia.

\subsection{Cultural Representations of the Source and Target Countries}

Four emerging themes have been examined based on the content analysis of the cultural representations between the source and target countries. They are Buddhism-oriented religious practices, Khmer-centered monoculturalism, tourism-driven English learning and over-representation of Japan as an imagined target culture.

\subsubsection{Buddhism-oriented Religious Practices}

Buddhism is considered as the national religion of Cambodia through legislative practice. The social and historical construction of Buddhism in Cambodia is associated with the unification of Cambodia as an independent country free from various colonial impacts in history (Hobsbawm \& Ranger, 1983). Article 43 of the Cambodia's constitution clearly states: "Buddhism is the religion of Cambodia." Meanwhile, more than 93 percent of the population believes in Buddhism, which plays an important role in the political and social life of the Cambodian people. Moreover, there are also other influential religions in Cambodia, including Islam, Catholicism, Primitive Religions and Brahmin.

Hobsbawm and Ranger (1983) assert the fact that Buddhism is not simply being recreated in its previous mold, but is being "reinvented" after a radical break with the past in Cambodia. Historically, Kent (2003) states that in pre-modern Cambodia, the cultural fabric of popular Buddhism/ animism played a central role in political and moral ordering in shaping Khmer ethnic and national identity and in nourishing fellowship among Cambodian villagers. Khmer Buddhism has played a crucial role in Cambodian culture for centuries both in the royal court and widely throughout the country. However, the role of religion in a country, apart from being consolidated and recognized by law, can also be solidified and practiced by all the people through education. The reproduction of Buddhism as national religion and legitimate forms of cultural interactions in daily life can be found through the English textbooks as indicated in Figure 3and 4.

In Figure 3, from the title, 'Unit 5-A homecoming: Monks, mangoes and a boat trip', we can see that the Monks (Buddhism) is a typical religious symbol of Cambodia. Addition to the title, the second picture also shows the monks who wear the Buddhist clothes. So the two figures show that monks in Cambodian English language 
textbooks are represented with both real and cartoon figures which are constituted as the legitimate member of Cambodian daily life.

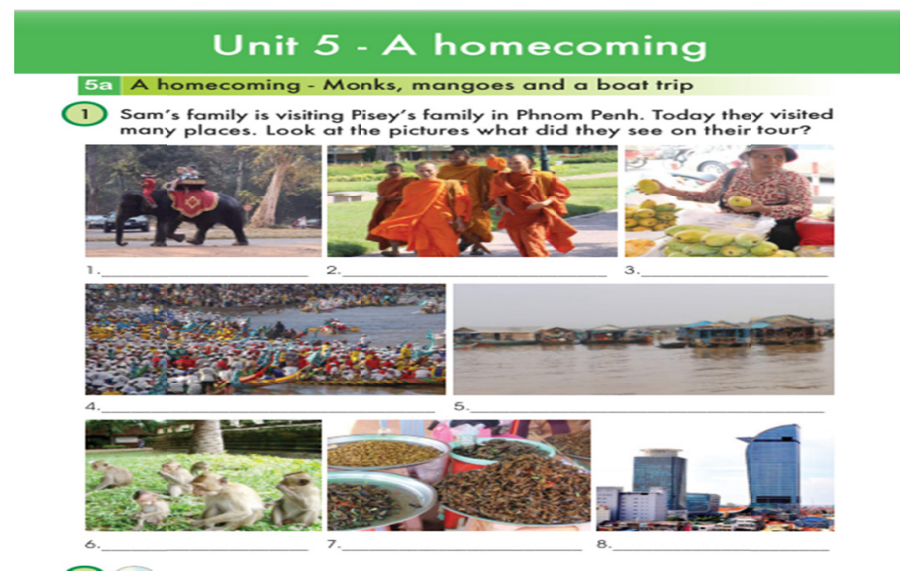

Figure 3. Student's Book, grade 8, Unit 5,P.38

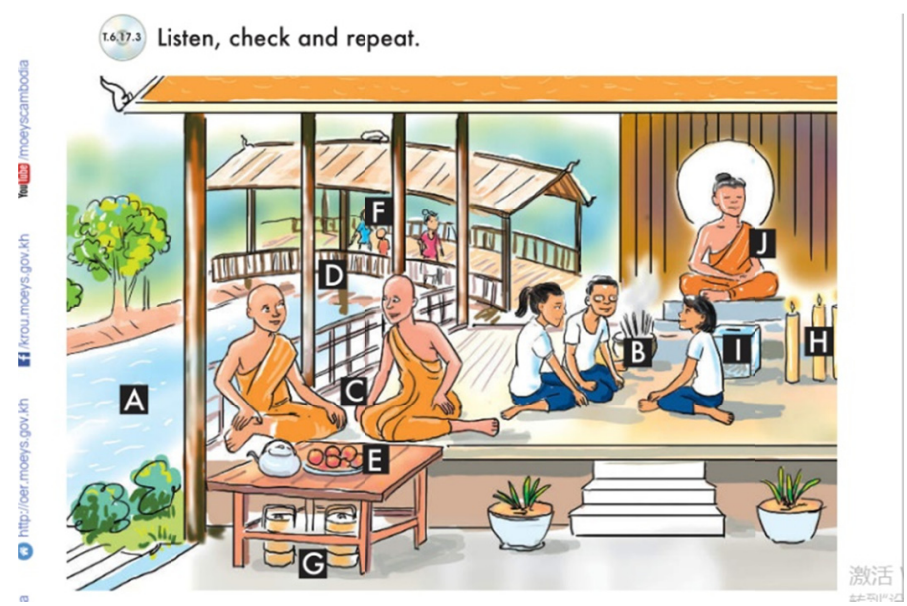

Figure 4. Student's Book, Grade 8, Unit 17, P.112

Constructing Buddhism as part of daily life can also be demonstrated through the shared stories within the family domain as indicated in Figure 5, 6,7and 8.

(2) Read the story and answer the question in your notebook.
\# Where did Piseth see the Buddha's head resting?
Early on our first day in Ayutthaya, it started raining. After watching the rain for about
half an hour, my dad said, 'I feel like going for a bicycle ride. Want to come?' I enjoy
learning about ancient culture and I didn't want to miss a great adventure with my
dad, so I said, 'Sure.'
By the time we reached the third temple the sun had started shining. My dad took
out his camera and began snapping pictures of the temple complexes. He is a
very artistic person. 3 Then with a click we'd continue riding.

Figure 5. Student's Book, Grade 9, unit 29, p.184

Figure 4 describes a Piseth's story of visiting some temples with her father. The purpose of her trip is to enjoy learning about the ancient religion. It indicates that in Cambodia, the religion education is embedded in daily life and family. 


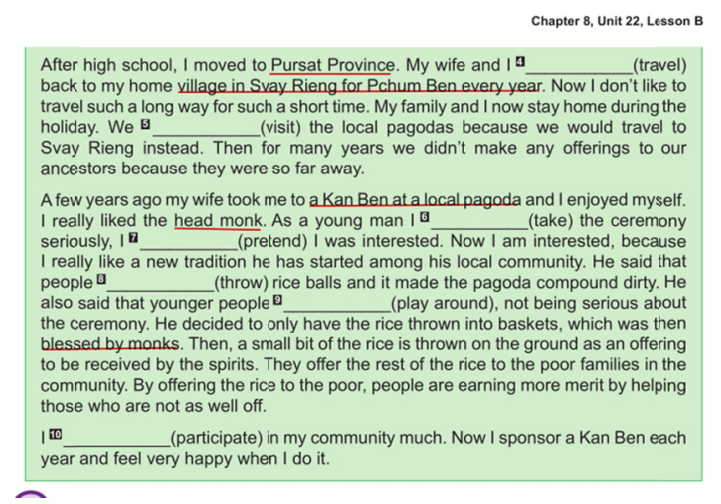

Figure 6. Student's Book, Grade 9, Unit 22, p.143

Similarly, Figure 6 also introduces a man's experience of travelling with his wife to visit the temples and monks. The man was interested in the tradition of Buddhism ceremony which the monks were praying and blessing for the poor families. By helping those who are not as well off, people can earn more merits. So, he decides to participant his local community.

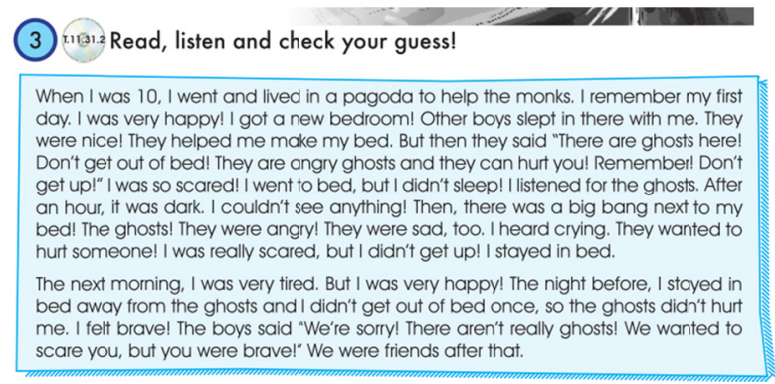

Figure 7. Student's Book, Grade 7, Unit 31, p.190

Figure 7 tells an interesting story when one boy was just 10 years old. In more details, it shows us a little boy's childhood experiences of living in pagodas. At that time, his friends pretended to scare him and said that there were ghosts there. Hearing this, he could not fall asleep. The next morning, he thought himself very brave. After that, he lived a happy life in the pagoda with many friends.

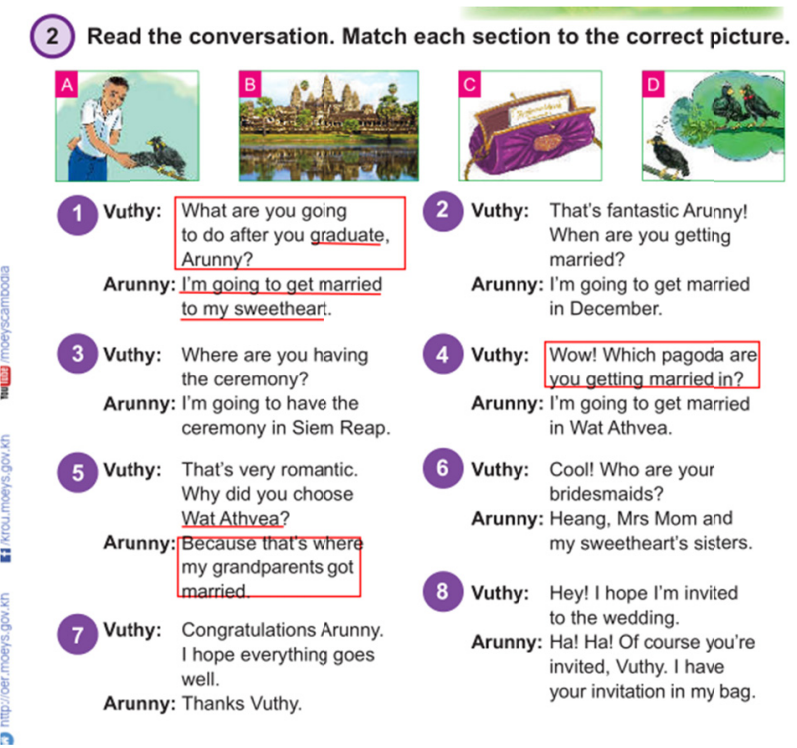

Figure 8. Student's Book, Grade 9, Unit 33, p.208

Further, Figure 8 shows a conversation between Vuthy and Arunny. After graduation, Arunny is going to marry and he chooses to hold his wedding ceremony in Wat Athvea pagoda, and he will invite Vuthy to participant his wedding. 
In short, the significance of Buddhism in Cambodia is reproduced via the representations of pagodas, monks (symbols of Buddhism) which appear frequently in different situations, such as in weddings, childhood experiences, traveling, visiting. Although Buddhism is highly promoted and widely represented in the textbooks, there is nothing about other religions such as Islam, Catholicism, Primitive Religions and Brahmin and so on, and non-Buddhism is also part of Cambodian daily life.

\subsubsection{Khmer-centered Monoculturalism}

In representing the home culture, Khmer, as the major ethnic group of Cambodian population, has become the only legitimate form of cultural communication even though Cambodia is a multi-ethnic, multicultural country with plentiful festivals and customs. The following figures respectively show the Khmer dance, clothes and festivals like Water Festival, Khmer New Year and Cambodian Independence Day.

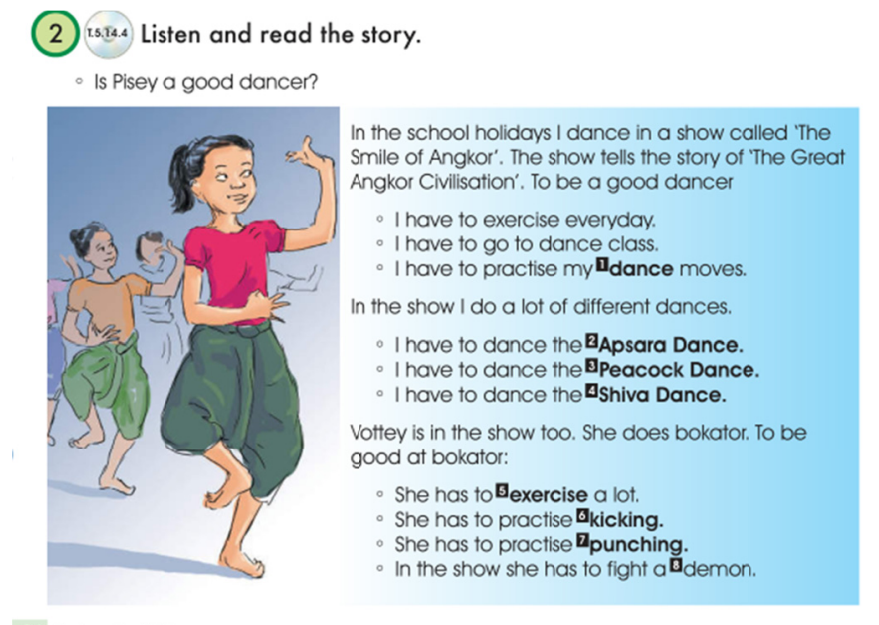

96 The beauty of Asia

Figure 9. Student's Book, Grade 8,Unit 14, p. 96

Obviously, Figure 9 shows us a traditional dance in Cambodia. It introduces the idea that in school holidays, they will dance the "Smile of Angkor" which tells the story of "the Great Angkor civilization". Additionally, dance names like Apsara Dance, Peacock Dance and Shiva Dance also show the religious influence of culture and customs. The reason is that 'Apsara' and 'Shiva' are deities in Cambodian religion.

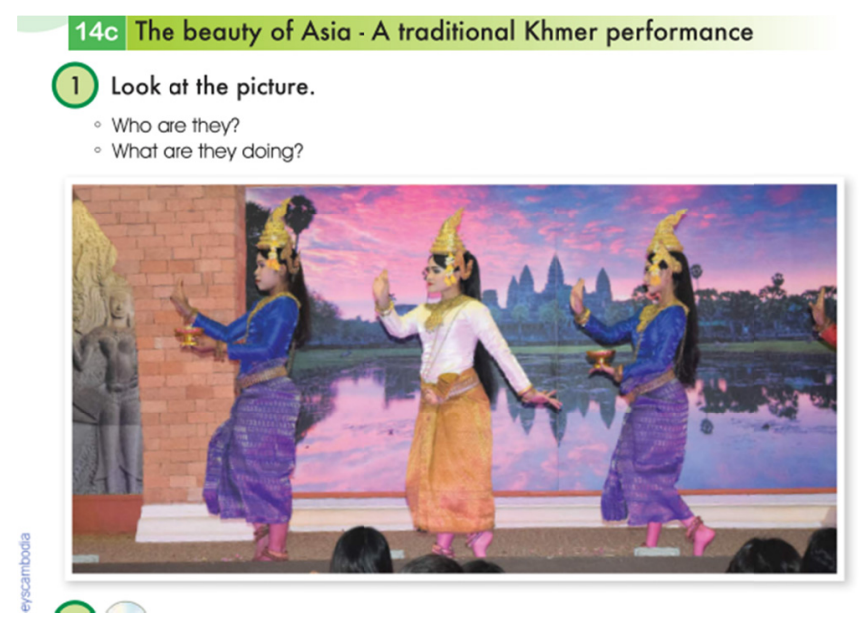

Figure 10. Student's Book, Grade 8, Unit 14, p. 96

In Figure 10, we can see different kinds of traditional clothes. In different performances, dresses are gorgeous with different styles and designs, and dancing gestures are also different (Student's Book, grade 8, Unit 14, p.97). As shown in Figure 10, most impressively, the traditional Khmer performance was seen as the beauty of Asia. 


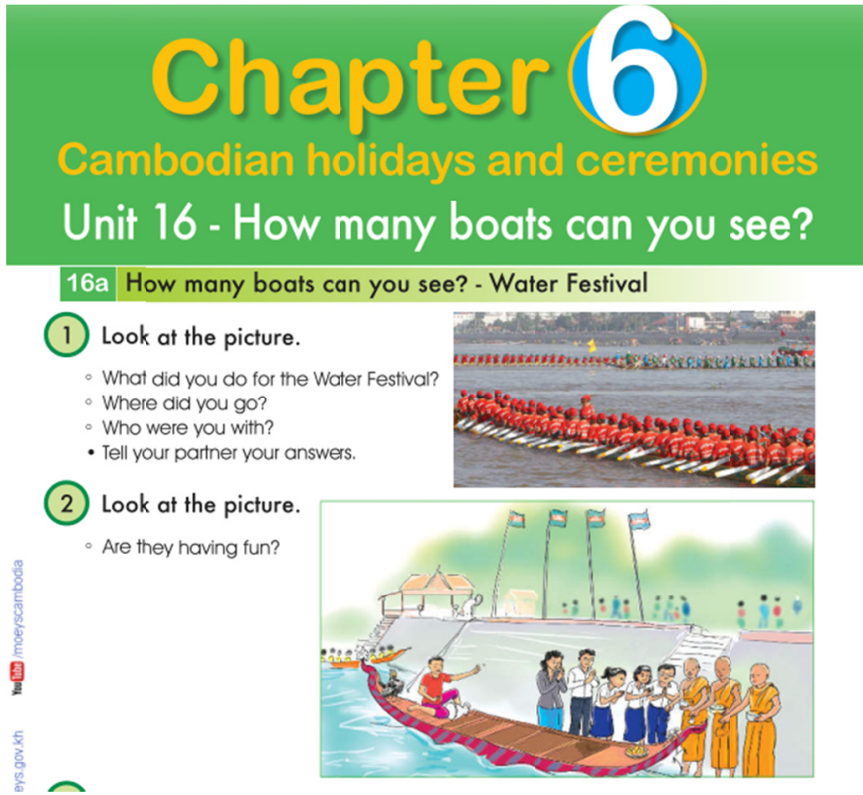

Figure 11. Student's Book, Grade 8, Unit 16, p.104

Figure 11 shows vivid pictures of the water Festival, particularly the boat races. At the same time, in the Student's Book, grade 9, it tells us Heang's thinking of the best ways to experience the Water Festival. He says that there are boat races and a beautiful boat parade in this festival. The text also describes the amazingly crowded situation in the Water Festival (Unit 24, P.154)
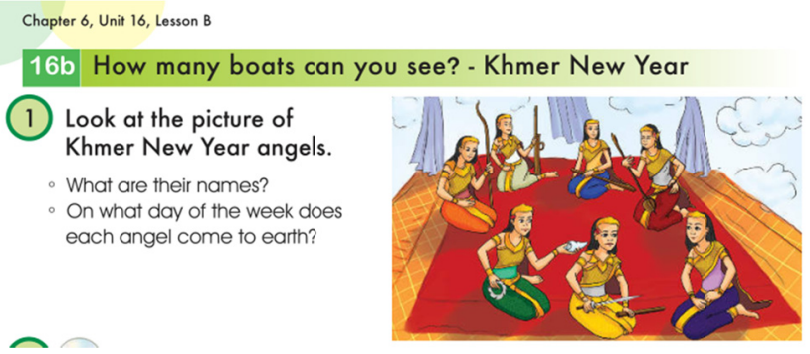

Figure 12. Student's Book, Grade 8, Unit 16, p.106

Figure 12 shows us the most essential festival-Khmer New Year in Cambodia. Through the pictures we see that these angels wear Cambodian traditional clothes and take some instruments or weapons for celebrating this festival.

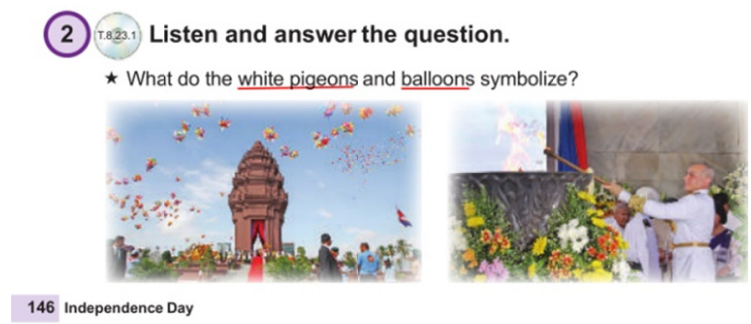

Figure 13. Student's Book, Grade 9, Unit 23, p.146

Meanwhile, Figure 13 shows us Cambodian Independence Day. Certainly, the White pigeons and balloons symbolize the peace and freedom of Cambodian people.

To Summarize, this part mainly displays the Cambodian Customs and festivals to the language learners.

\subsubsection{Localized English Variety Driven by Tourism}

Tourism constitutes the main industry in Cambodia with 4.35 billion U.S dollars in 2018, up 19.8 percent from 3.63 billion dollars in a year earlier according to Tourism Minister Thong Khon because of the economic 
significance of learning English to serve the tourism industry, the cultural elements of national scenic spots and city is highly represented in the textbooks.

As we all know, Cambodia is rich in tourism resources, such as Angkor Wat, one of the "Seven Wonders of the World", which symbolizes the long history and splendid civilization of Cambodia. In most English language textbooks, when introducing a country, tourism is often one of the hot attracting topics. Accordingly, Cambodian tourism is represented in the following text.

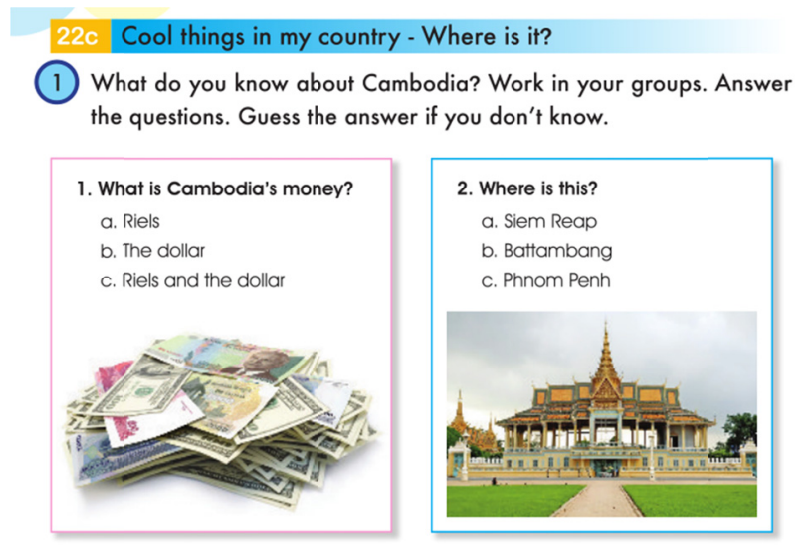

Figure 14. Student's Book, Grade 7, Unit 22, p.138

Figure 14 shows several famous cities in Cambodia, particularly referring to tourism. Siem Reap is a popular resort town as the gateway to Angkor region. Phnom Pehn is the capital and largest city of Cambodia, located on the banks of the Tolne Sap and Mekong River. Also, Battambang is well known for being the leading rice-producing province of the country, a major commercial hub.

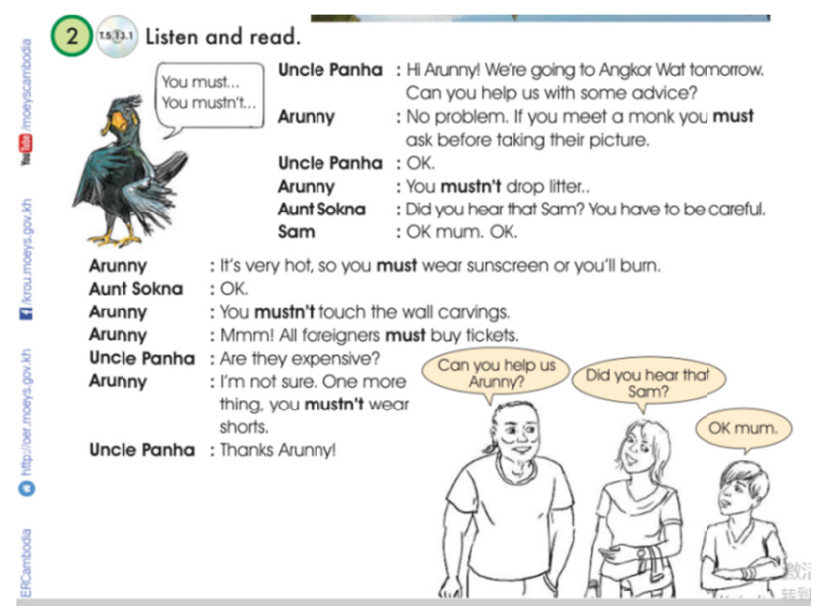

Figure 15. Student's Book 8,Unit 13, p. 86

Figure 15 shows a dialogue about a Cambodian famous scenic spot—Angkor Wat. Angkor Wat was first a Hindu, later a Buddhist, temple complex in Cambodia and the largest religious monument in the world. Its mystery and grandeur attracted quantities of tourists around the world. In a word, tourism is an important economic income for Cambodia.

\subsubsection{Japan as an Imagined Community for Cambodian Cross-Cultural Communication}

The above analysis tends to indicate that the representation of Cambodian culture is prominent from the aspects of religion, customs, festivals and tourism. On the other hand, the most striking and interesting finding is that there is over-representation of Japanese culture in the three textbooks. As mentioned in the section of material selection, the researcher found that in the cover of this series book has two symbols of Japan, one is 'THE NIPPON FOUNDATION' and, the other is 'Education Support Center KIZUNA NGO'. This indicates that Japan's obvious education support to Cambodia. Then, how about the content of the three textbooks? Are there any representations of Japanese culture in the books? Certainly it there is. The following figures will represent this point clearly. 
6) Write about your amazing experiences using the pictures below. Choose three things you have done and three things you haven't.
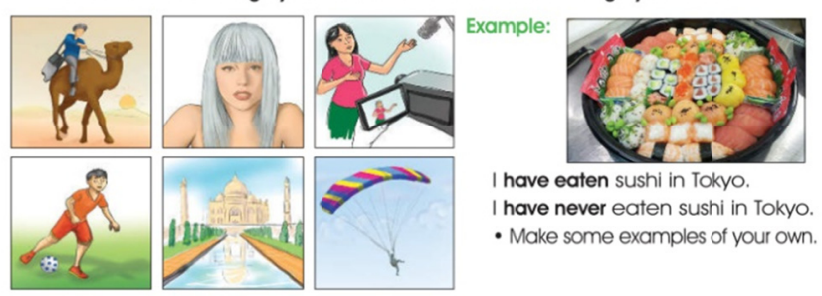

What have they done? 195

Figure 16. Student's Book, Grade 8, Unit 31, p. 195

In the right side picture of Figure 16, we can clearly see the Japanese famous food-Sushi. It is very famous and warmly welcomed by many people in the world, also including Cambodian people.

\section{Unit 11 - We love to play sports}

11a We love to play sports - The Karate kid from Japan

(1) Look at the picture of Ken.

- Where is he from?

What's he doing?

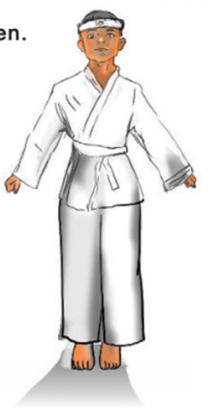

Figure 17. Student's Book, Grade 8, Unit 11, p.74

The above Figure shows Japan's famous food. Figure 17 represents Japanese well-known sport-Karate. In the picture, the man wears Karate clothes as well.

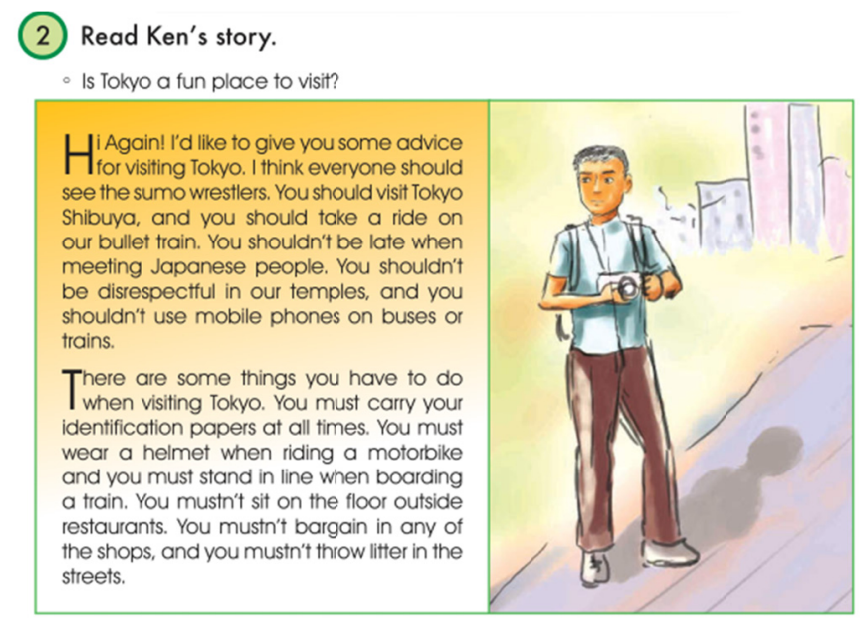

94 The beauty of Asia

Figure 18. Student's Book, Grade 8, Unit 14, p.94

This short text recommends people to travel in Tokyo in Japan, and also gives some suggestions on how to visit Japan. It is interesting that in the short text, the writer of the book uses "should; shouldn't; must; mustn't" for giving advice. The tone of voice is so serious, even stronger than introducing Cambodian scenic spots.

Figure 19 shows the famous musical instrument-Koto in Japan. It introduces a Japanese Ken's hobbies and his talents in music. 


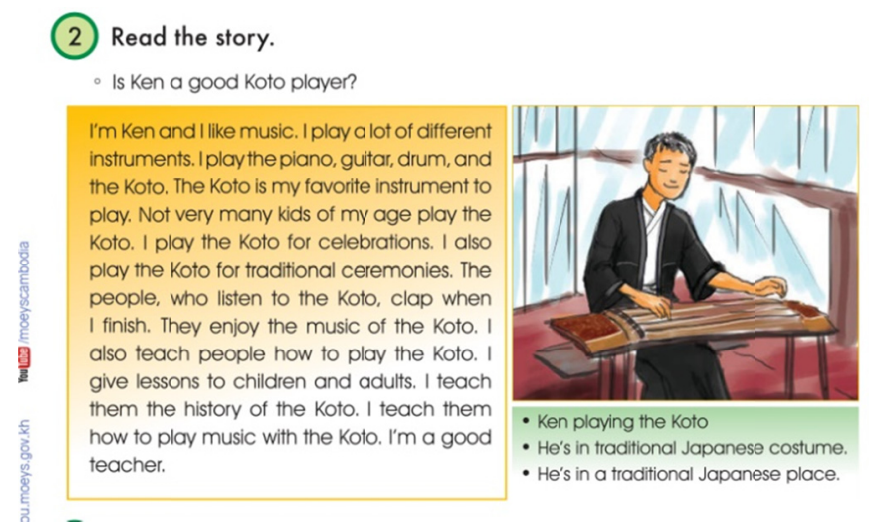

Figure 19. Student's Book, Grade 8, Unit 15, p.100

Overall, in this section, it examines four prominent findings: Buddhism-oriented religious practices; Khmer-centered monoculturalism; tourism-driven English learning and over-representation of Japan as imagined target culture in three MoEYS series textbooks used in Cambodia.

\section{Discussion and Implications}

Based on the findings, the study would extend our discussion into three aspects. First, the occupations of Cambodian characters and foreign characters are different and imbalanced in light of social class. Such contrastive representations of target and source characters are the social reproduction of the unequal positioning of seeing the locals as economically inferior and lack of social respect and the foreigners as socially superior and desirable communicators. Such social positioning is also associated with the global system where Cambodia is situated in the least developed list and where service industry and agriculture constitute the main source for Cambodian economy where other profitable or socially desired job positions are not represented. Second, there is under-representation of non-Khmer customs and festivals, such as western customs and festivals, demonstrating the essentialism in the three textbooks. However, it is questionable whether such representation of targeting countries might bridge the cross-cultural understanding of the language learners. Third, as English language textbooks, the content should be distributed equally. However, in the three textbooks, besides Cambodian characters and culture, Japanese characters and culture appear the most. This will influence the language learners unconsciously. They might think that Japan is so great. Everything in Japan is the best. They might worship Japanese culture and are eager to live a Japanese life.

The findings also have several implications. First, Cambodian English has been used to promote the local culture and customs. In the English textbooks, Cambodia is constructed as a tourism-centered country where various scenic spots and local customs and practices are widely introduced in English and such new forms of promoting Cambodian English is for the purpose of promoting the Cambodian tourism resources. We argue that such tourism-driven English learning content is embedded in the wider context of Cambodian socio-political process in which tourism constitutes the main profitable industry. Many localized forms of English expressions have, therefore, been spotted like the naming practice for the local people and scenic spots. Being exposed to such English variety, Cambodian English learners are expected to introduce their local culture and customs in English to the outside world, and thus enhancing the local tourism industry and the national image of Cambodia.

Second, our findings indicate that there are unbalanced cultural representations for the targeting countries. The so-called western culture is exclusively dominated by English regime where English speaking countries are more likely to be produced in the textbooks, followed by the post-colonial countries of speaking English as official or national language. Other non-English speaking countries are largely excluded from the textbooks. We argue that these textbooks only reproduce the hegemonic order of English world, which is hierarchical and consequential. The foreign speakers depicted in the textbooks are constructed as knowledgeable, acquiring decent social status; in contrast, the local people appear to be socially inferior by taking up less challenging jobs mostly working in service industry.

The third implication is associated with the monoculturalism in that Buddhism and Khmer are the only legitimate forms for promoting the source culture. Despite the fact that there are more than 20 ethnic groups living in Cambodia, there is predominantly coverage of the customs and cultural practices of Khmer people whereas other ethnic groups remain unknown. Such homogenized cultural representation is also found in representing Buddhism as the national religion in Cambodia. The Buddhist monks, habitual customs and 
Buddhist history and scenic spots are used as cultural icons to present Cambodian culture and Buddhism-related social and cultural activities are constructed as daily part of mundane life. As a consequence, other religious practices are overlooked and thus marginalized from the mainstream social discourse.

As a member of ASEAN, Cambodia sees the importance of teaching English to the young generation in order to embrace the world in the globalized era. However, the imagined community for Cambodian youth to use English for communication is de facto with Japanese people. The analysis of three textbooks for Cambodian students indicates that Japan-related cultural forms constitute a prominent part of learning content. Both the value of learning about Japanese culture and the importance of getting to know Japan as an imagined country have been depicted in the textbooks as important learning resources for Cambodian youth to get exposed to. We argue that such over-representation of Japan in Cambodian English textbooks, aiming to manipulate Cambodian youth by imparting Japanized knowledge. Such social practice and ideological education correlate with the fact that the funding resource for compiling the English textbooks for Cambodian government is largely supported by Japan. In other words, the cultural elements represented in the English textbooks do not serve the common good but a small group of people from a particular country.

\section{Conclusion}

In conclusion, English is used in the textbooks to introduce Cambodia to the outside world by attracting tourists from all over the world. However when it comes to the distribution of targeting countries and imagined interlocutors, there are Anglophone-based, Khmer-centered homogeneity and Japan-oriented representations. In order to make a more balanced evaluation of English textbooks in Cambodia, future studies should be conducted by comparing different materials produced in different social contexts for better understanding of sociopolitical forces upon Cambodia.

\section{References}

Aiello, G. (2006). Theoretical advances in critical visual analysis: Perception, ideology, mythologies, and social semiotics. Journal of Visual Literacy, 26(2), 89-102. https://doi.org/10.1080/23796529.2006.11674635

Apple, M. W. (1990). Ideology and Curriculum (2nd ed.). London: Routledge.

Alshammri, A. F. K. (2017). Evaluating the representations of identity options and cultural elements in English language textbooks used in Saudi Arabia. This thesis is presented as a partial fulfillment to the requirements for the Master of Research.

Canale, G. (2016). (Re) Searching culture in foreign language textbooks, or the politics of hide and seek. Language, Culture and Curriculum, 29(2), 225-243. https://doi.org/10.1080/07908318.2016.1144764

Cavanagh, S. (1997). Content analysis: concepts, methods and applications. Nurse Researcher, 4(3), 5-16. https://doi.org/10.7748/nr1997.04.4.3.5.c5869

Crystal, D. (2003). English as a global language (2nd ed.). Cambridge: Cambridge University Press. https://doi.org/10.1017/CBO9780511486999

Fairclough, N. (1995). Critical discourse analysis: The critical study of language. London: Longman.

Gee, J. P. (1990). Social linguistics and literacies: Ideology in discourses. London: Falmer Press.

Graddol, D. (2006). English next. Why global English may mean the end of 'English as a foreign language'. London: The British Council.

Gramsci, A. (1971). 1971 Selections from the Prison Notebooks. London: Lawrence and Wishart.

Hobsbawm, E., \& Ranger, T. (1983). The Invention of Tradition. New York: Cambridge University Press.

Hodkinson, A., Ghajarieh, A., \& Salami, A. (2018). An analysis of the cultural representation of disability in school textbooks in Iran and England. Education 3-13, 46(1), 27-36. https://doi.org/10.1080/03004279.2016.1168861

Hyatt, D. (2005). A Critical Literacy Frame for UK secondary education contexts. English in Education, 39(1), 43-59. https://doi.org/10.1111/j.1754-8845.2005.tb00609.x

Jenkins, J. (2015). Global Englishes. A resource book for students (3rd ed.). New York: Routledge. https://doi.org/10.4324/9781315761596

Julie, G. (2004). Complex regional multilateralism: 'Strategising' Japan's responses to Southeast Asia. The Pacific Review, 17(1), 71-94. https://doi.org/10.1080/0951274042000182429

Kasanga, L. A. (2012). Mapping the linguistic landscape of a commercial neighbourhood in Central Phnom Penh. 
Journal of Multilingual and Multicultural Development, 33(6), 553-567. https://doi.org/10.1080/01434632.2012.683529

Kent, A. (2003). Recovery of the collective spirit: The role of the revival of Buddhism in Cambodia. Department of Social Anthropology, Goteborg University, Working Paper 8.

Lee, J. F., \& Collins, P. (2010). Construction of gender: A comparison of Australian and Hong Kong English language textbooks. Journal of Gender Studies, 19(2), 121-137. https://doi.org/10.1080/09589231003695856

Li, J., Ai, B. \& Zhang, J. (2019). Negotiating language ideologies in learning Putonghua: Myanmar ethnic minority students' perspectives on multilingual practices in a borderland school. Journal of Multilingual and Multicultural Development.1-14.

Li, J., Dong, J. \& Li, X. (2019). The Multiple Ideologies of Shaping Cambodian Students' Language Learning Experiences at Chinese Universities. Journal of English Language Teaching. 1-9.

Mahamood, M. A., Asghar, Z. M., \& Hussain, Z. (2012). Cultural representation in ESL textbooks in Pakistan: A case study of 'Step Ahead 1'. Journal of education and practice, 3(9), 35-42.

Mohamed, M. A. (2014). The Representation of the Orient in English Language Textbooks Used in Libyan Secondary Schools (Doctoral dissertation, University of Sheffield).

Moore, S., \& Bounchan, S. (2010). English in Cambodia: Changes and challenges. World Englishes, 29(1), 114-126. https://doi.org/10.1111/j.1467-971X.2009.01628.x

Neau, V. (2003). The teaching of foreign language in Cambodia: A historical perspective. Language, Culture and Curriculum, 16(3), 253-268. https://doi.org/10.1080/07908310308666673

Paltridge, B. (2006). Discourse analysis. Continuum: London.

Peled-Elhanan, N. (2012). Palestine in Israeli school books: Ideology and propaganda in education. London: I. B. Tauris \& Co.

Richardson, J. (2007). Analysing Newspapers: An Approach from Critical Discourse Analysis. London: Palgrave Macmillan. https://doi.org/10.1007/978-0-230-20968-8

Robert, P. W. (1990). Basic Content Analysis (2nd ed.). Sage Publications, The International Professional Publishers Newbury Park London New Delhi Harvard University.

Stranger-Johannessen, E. (2015). Constructing English as a Ugandan language through an English textbook. Language, Culture and Curriculum, 28(2), 126-142. https://doi.org/10.1080/07908318.2014.987296

Taira, K. (2019). A systematic form of Japanization in Okinawa: Japanese identity construction through a Japanization discourse in textbooks and a textbook guide. International Studies in Sociology of Education, 28(2), 110-126. https://doi.org/10.1080/09620214.2018.1554448

Tweed, A. D., \& Som, M. (2015). English language education in Cambodia and international support ahead of ASEAN integration. ASEAN integration and the role of English language teaching, 13-40. Phnom Penh: IELTS.

Wooffitt, R. (2005). Conversation Analysis and Discourse Analysis: A Comparative and Critical Analysis. London: Sage Publication Ltd. https://doi.org/10.4135/9781849208765

Yamada, M. (2010). English as a multicultural language: implications from a study of Japan's junior high schools' English language textbooks. Journal of Multilingual and Multicultural Development, 31(5), 491-506. https://doi.org/10.1080/01434632.2010.502967

Zein, S. (2017). Access policy on English language education at the primary school level in the ASEAN Plus Three member states: motivations, challenges and future directions. Asian Englishes, 19(3), 197-210. https://doi.org/10.1080/13488678.2017.1389063

\section{Copyrights}

Copyright for this article is retained by the author(s), with first publication rights granted to the journal.

This is an open-access article distributed under the terms and conditions of the Creative Commons Attribution license (http://creativecommons.org/licenses/by/4.0/). 